\title{
KONSUMSI GADGET SISWA SEKOLAH DASAR MUHAMMADIYAH KOTA YOGYAKARTA
}

\author{
Lilik Kurniawati Uswah \\ lilik_uswah2007@yahoo.co.id
}

\begin{abstract}
Digital natives refer to a generation that favours speed, whereby communication is done quickly and the information is spread instantly. There is a worry against social and cultural implication of the use of gadget among children. There is also another worry against the impact of mass culture to the mindset and lifestyle of the young generation and the community in general. New technology is suspected as being used more for recreational rather than educational purposes. Productive activities such as learning, socializing, and deeper probing of precious traditional values will simply be replaced by intense exposure to receational information technology. The study aims at 1) comprehensively identifying gadget consumption behavior of school children at Muhammadiyah elementary school of Yogyakarta Municipality using descriptive method that describes naturally the phenomena and condition with no hypothesis. Informants of the study are gadget users of 10-12 years old at Muhammadiyah elementary schools of Yogyakarta Municipality, i.e. Sokonandi, Karangkajen and Pakel Muhammadiyah elementary schools; 2) describing the behavior and the practice of using gadget by respondents. Interview is conducted freely, even some of the respondents are unaware they are being interviewed. Data are collected through ethnographic approach, by developing the relation between the interviewer and interviewee.

The result show that there is no need to worry about the use of gadgets in Muhammadiyah School of Yogyakarta Municipality.
\end{abstract}

Keywords: gadget, digital natives, consumption

\section{Abstrak}

Digital natives adalah generasi yang mengutamakan kecepatan, di mana komunikasi dapat cepat dilakukan dan informasi sangat cepat tersebar. Muncul kekhawatiran mengenai implikasi sosial budaya dari penggunaan gadget terhadap pola konsumsi anak. Dampak budaya massa terhadap pola pikir dan gaya kaum muda dan masyarakat umumnya. Diduga teknologi baru ini akan digunakan untuk rekreasi dan bukan edukasi. Kegiatan-kegiatan produktif seperti belajar, sosialisasi, pendalaman nilainilai tradisional yang luhur akan dialihkan menjadi kegiatan penggunaan teknologi informasi yang rekreatif. Penelitian sederhana ini bertujuan untuk memahami secara komprehensif perilaku konsumsi gadget bagi anak yang bersekolah di SD Muhammadiyah Kota Yogyakarta. Informan yang digunakan dalam penelitian ini adalah anak-anak pemakai gadget yang berusia 10-12 tahun yang bersekolah di SD Muhammadiyah di Kota Yogyakarta, yakni SD Muhammadiyah Sokonandi, SD Muhammadiyah Karangkajen, dan SD Muhammadiyah Pakel.

Penelitian ini bertujuan untuk memberikan gambaran tentang perilaku dan praktik konsumsi media gadget melalui metode deskriptif, yakni menggambarkan secara alami tentang gejala dan keadaan dengan tidak menggunakan hipotesis. Wawancara dilakukan bebas, sambil lalu, bahkan kadang tidak disadari oleh informan sendiri. Pengumpulan data dengan jenis pendekatan etnografis dilakukan dengan beberapa cara, salah satunya dengan etnografi kontemporer adalah memilih dan membangun relasi yang dekat dengan individual sang informan. Metode yang digunakan dalam penelitian ini adalah etnografi.

Hasil penelitian menunjukkan bahwa sebenarnya tidak ada yang perlu dicemaskan dalam penggunaan 'gadget" di sekolah dasar Muhammadiyah di Kota Yogyakarta

Kata kunci: gadget, digital native, konsumsi, siswa sekolah dasar 


\section{PENDAHULUAN}

Generasi yang lahir setelah era '90-an secara popular disebut sebagai the digital native. Generasi ini melek di dunia langsung melihat internet dan piranti teknologi (gadget) sebagai bagian tidak terpisahkan dari kehidupan, setara dengan makan dan minum. Generasi ini terikat dengan gadget dan tidak mempunyai hambatan mengoperasikan peralatan komunikasi serumit apapun, apalagi mengakses teknologi komputer.

Kebiasaan berperilaku dekat dengan gadget, membuat generasi ini cepat membaca dan menguasai bahasa asing serta kemampuan lain yang tidak pernah terbayangkan sebelumnya. Miliaran website di internet menjadikangenerasi ini memiliki cara berpikir yang berbeda dalam memandang gadget, memproses informasi dan berkomunikasi. Dapat dikatakan, generasi ini menghabiskan sebagian waktunya di dunia maya dengan gadget atau piranti teknologi yang selalu tersedia, misal: $i$-phone, blackberry, ipad, handphone, tablet, laptop, maupun komputer PC.

Digital natives adalah generasi yang mengutamakan kecepatan, di mana komunikasi dapat cepat dilakukan dan informasi sangat cepat tersebar. Akibatnya, mereka cenderung untuk melakukan segala hal dan menginginkan sesuatu dengan cepat.

Generasi digital tidak menyukai segala sesuatu yang konvensional dan standar. Mereka senang dengan segala yang baru dan inovatif. Dapat dibayangkan betapa jenuhnya anak-anak ini ketika membaca buku teks di sekolah yang masih memakai pendekatan linear dan konvensional. Mereka sangat menghargai kebebasan, mulai dari kebebasan memilih hingga kebebasan berekspresi. Hal ini tentu tidak lepas dari content yang tersedia dalam gadget yang mereka gunakan. Tidak heran jika digital natives menganggap kebebasan sebagai salah satu nilai penting dalam kehidupannya.

Don Tapscott dalam buku "Grown up Digital" (2009) banyak mengulas tentang digital natives atau Generasi $Z$ ini. Sebuah pengamatan mendalam tentang generasi yang tumbuh sejak awal era digital, diungkapkan bahwa selain membawa banyak keajaiban dalam bidang ilmu pengetahuan dan komunikasi, ada sisi gelap yang melanda generasi ini, antara lain gadget membuat mereka anti sosial dan apatis.

Di sisi lain, pendidikan dasar yang berbasis ideologi keislaman di Indonesia saat ini sangat ketat dalam membuat aturan pemakaian gadget (terutama) di sekolah. Ketika berada di luar sekolah, kecenderungan anak dalam pemakaian gadget akan semakin meluap karena sudah tidak lagi ada sekat atau aturan yang diberikan kepada si anak.

Salah satu bentuk ketegangan dan kemelut yang terjadi akibat penetrasi media adalah hancurnya nilai-nilai tradisional dan masuknya nilai-nilai modern yang destruksif. Munculnya gadget sebagai media informasi mutakhir sarat dengan pesan-pesan yang mendorong perilaku ke arah seksual (sexual permissiveness), perilaku agresif (aggressiveness), konsumerisme dan sekulerisme. Inilah yang dikhawatirkan dalam pendidikan dasar kemuhammadiyahan.

Masuknya piranti teknologi (gadget) dan berkembangnya sistem informasi yang "computer based" membawa dampak baru, positif dan negatif. Pada sisi yang negatif Ziauddin Sardar dalam Information and the Moslem World menunjukkan bahwa penggunaan gadget dan komputer secara menyeluruh dapat menghancurkan prinsip-prinsip etika Islam: tawhid, khilafah, 'adl, 'ibadah, dan hikmah. Pada sisi yang positif, komputer dan gadget memungkinkan penerimaan, pengolahan, dan penyampaian informasi tentang masalah-masalah umat yang lebih cepat, lengkap, dan cermat. Komputer serta gadget memungkinkan kita menetapkan prinsip Syura, salah satu nilai sosial dasar umat Islam.

Muncul kekhawatiran mengenai implikasi sosial budaya dari penggunaan gadget terhadap pola konsumsi anak dan dampak budaya massa terhadap pola pikir dan gaya kaum muda dan masyarakat umumnya. Diduga teknologi baru ini akan digunakan untuk rekreasi dan bukan edukasi. Kegiatan-kegiatan produktif seperti belajar, sosialisasi, pendalaman nilai-nilai tradisional yang luhur akan dialihkan menjadi kegiatan penggunaan teknologi informasi yang rekreatif. Apakah memang begitu?

Orang tua dan guru adalah digital immigrants, yakni mereka yang telah mengadopsi dan menggunakan teknologi terkait, tetapi lahir sebelum kemunculan era digital. Digital immigrants belajar bagaimana membuat serta menggunakan e-mail dan jejaring sosial serta menggunakan piranti teknologi tersebut. Namun, proses itu semua berlangsung "terlambat" dibandingkan digital natives, yang mengenyam teknologi tersebut sejak masih usia SD, bahkan sejak lahir.

Digital natives belajar, bekerja, menulis, dan berinteraksi dengan orang lain melalui cara yang berbeda dengan generasi sebelumnya. Bagaimana sesungguhnya mereka mengonsumsi gadget dalam 
keseharian?

Dari latar belakang permasalahan di atas maka rumusan masalah dalam penelitian ini adalah: Bagaimana perilaku konsumsi media gadget bagi siswa Sekolah Dasar Muhammadiyah di Kota Yogyakarta?

Untuk memahami secara komprehensif perilaku konsumsi gadget siswa yang bersekolah di SD Muhammadiyah Kota Yogyakarta, maka pertanyaan yang diajukan dalam penelitian adalah:

1. Sejak kapan siswa SD Muhammadiyah di Kota Yogyakarta menggunakan gadget? Gadget apa saja yang digunakan?

2. Content apa saja yang biasa dikonsumsi? Bagaimana anak-anak memperlakukan gadget dalam kehidupan sehari-hari?

\section{TINJAUAN PUSTAKA}

\section{Teori Konsumsi}

Konsumsi muncul sebagai perhatian budaya pada akhir 1950-an dan awal 1960-an dalam perdebatan " mengenai perkembangan 'masyarakat konsumen'. Ia kemudian menjadi sangat tampak di dalam cultural studies pada tahun 1970-an di dalam karya mengenai bagaimana pelbagai subkultur menyediakan beragam komoditas untuk menghasilkan makna alternatif dan oposisional. Baru-baru ini, konsumsi bisa ditemukan dalam pelbagai studi mengenai budaya penggemar (fan culture) dan studi tentang belanja sebagai bentuk budaya pop (Storey, 2006:143).

Bagi Karl Marx dan Frederick Engels, transisi dari feodalisme ke kapitalisme adalah suatu transisi dari produksi yang digerakkan oleh kebutuhan menuju produksi yang digerakkan oleh keuntungan. Selain itu, di dalam masyarakat kapitalis, para buruh membuat barang-barang demi mendapatkan upah. Mereka tidak memiliki barang-barang itu; barangbarang itu dijual ke pasar dengan perolehan keuntungan. Oleh karena itu, untuk mendapatkan barang-barang para buruh harus membelinya dengan uang. Jadi, para pekerja menjadi 'konsumen', dan kita menyaksikan munculnya 'masyarakat konsumen' (Storey, 2006:144).

Herbert Marcuse mengembangkan deretan argumen ini, untuk menunjukkan bahwa ideologi konsumerisme mendorong kebutuhan palsu dan bahwa kebutuhan ini bekerja sebagai satu bentuk kontrol sosial. Orang-orang itu mengenali diri mereka di dalam komoditas mereka, mereka menemukan jiwa mereka di dalam mobil, perangkat wi-fi?, rumah bertingkat, perlengkapan dapur. Mekanisme itu sendiri, yang mengikatkan individu pada masyarakatnya telah berubah dan kontrol sosial dilabuhkan pada kebutuhan-kebutuhan baru yang telah dihasilkan (Storey, 2006:145).

Pierre Bourdieu menggeser argumen dari apa yang dilakukan konsumsi kita menjadi bagaimana kita menggunakan konsumsi untuk tujuan pembedaan sosial. Ia berpendapat bahwa budaya hidup (gaya hidup dan lain-lain) adalah suatu area penting bagi pertarungan di antara pelbagai kelompok dan kelas sosial. Bagi Bourdieu, konsumsi budaya itu cenderung sadar dan disengaja atau tidak, mengisi suatu fungsi sosial berupa legitimasi perbedaan sosial (Storey, 2006:146).

\section{Konsumsi Media}

Konsumsi sering direduksi atau dipahami sebagai suatu proses atau yang melibatkan pembelian dan pertukaran ekonomis, dengan konotasinya cenderung negatif pula, yakni sebagai tindakan pemborosan (waste) dan conspicuous, "jorjoran" atau pamer (display) (Budiman, 2002:18).

Khususnya kaitannya dengan proses komunikasi bermedia (mediated communication), konsumsi pun kadang dipadankan dengan tindakan membaca (reading) dengan menguraikan isi (decoding), seperti yang dilakukan oleh Pierre Bourdieu dan Stuart Hall. Di dalam kajian ini gagasan pokok mengenai konsumsi akan lebih difokuskan sebagai suatu aktivitas dan proses sosial yang aktif. Sedangkan definisi antropologis mengenai konsumsi, sebagaimana pernah diusulkan oleh Mary Douglas dan Baron Isherwood, yakni sebagai pemakaian atas milik-milik material, segala jenis tindakan penggunaan benda-benda. Atau, mengikuti Michael de Carteau, konsumsi meliputi berbagai prosedur mengenai hal-hal yang diperbuat atau dilakukan oleh konsumen dengan produk tertentu, cara memakai produk. Konsumsi merupakan sebuah seni atau "cara berbuat", sebagai "seni berbuat" ini dan itu, meliputi "cara mengoperasikan" atau melakukan sesuatu (Budiman, 2002:19).

Selain melibatkan pemakaian produk-produk, konsumsi juga merupakan suatu tindakan, suatu proses yang dihidupkan melalui berbagai praktik. Aktivitas menggunakan gadget, misalnya, sebagaimana halnya aktivitas konsumsi yang lain, adalah sebuah proses aktif, antar-partisipan maupun antara partisipan dan gadget, yang di dalamnya 
audiens tidak sekedar mengambil peran sebagai pihak yang secara aktif memilih aneka material media yang tersedia bagi mereka, melainkan juga aktif memakai, menafsir, serta mengawasandi (decoding) material-material yang dikonsumsinya. Artinya, menggunakan gadget bukanlah sekedar aktivitas menyorotkan mata ke arah layar gadget, melainkan bersifat multifaset dan kaya dimensi. Pemakai gadget tidak hanya membuat interpretasinya sendiri, melainkan juga mengkonstruksikan situasi-situasi dan cara-cara praktik menggunakan piranti teknologi itu dilakukan pada saatnya sebagai suatu tahap di dalam proses komunikasi. Proses komunikasi itu sendiri, seperti dirumuskan oleh Stuart Hall, tersusun dari momenmomen yang terkait namun saling berbeda dan relatif otonom, yakni produksi, sirkulasi, konsumsi (baca: pemakaian, penerimaan), serta reproduksi. Menggunakan gadget merupakan suatu praktik di dalam momen komunikasi: sebuah momen yang menurut Michel de Certeau, menjadi fokus terpenting di dalam budaya kontemporer (Budiman, 2002:21).

Kajian ini meminjam pendekatan mode konsumsi (mode of consumption) yang mengambil sudut pandang antropologis. Pendekatan mode konsumsi berpendirian bahwa terdapat kemiripan dan perbedaan dalam konsumsi budaya di dalam setiap masyarakat. Dengan berfokus pada persoalan konsumsi budaya, pendekatan ini mengarahkan perhatiannya kepada pengalaman dan pemakaian benda-benda kultural dengan penekanan pada praktik-praktik konsumsi yang aktual. Pendekatan mode konsumsi melihat konsumsi kultural di dalam kerangka sosial yang menandakan bahwa konsumsi adalah sungguh-sungguh bersifat sosial, relasional, dan aktif, alih-alih bersifat pribadi, atomik dan pasif (Budiman, 2002:23).

\section{Konsumsi Gadget dan Perubahan Sosial}

Para ahli komunikasi telah sepakat bahwa sekarang telah terjadi arus informasi satu arah. Kita masih tetap saja dibanjiri informasi dari Barat. Akibatnya, apa yang dianggap penting oleh Barat kita anggap penting pula. Apa yang mereka abaikan, kita abaikan pula. Anak-anak muda akan lebih hafal riwayat Mick Jagger, Michael Jackson, budaya KPop daripada pahlawan-pahlawan nasional mereka. Mereka lebih mengetahui kecelakaan lalu lintas di sudut kota New York daripada peristiwa-peristiwa kelaparan di negeri sendiri. Inilah barangkali yang menyebabkan banyak anak muda tercerabut dari akar budaya dan masyarakatnya, teralienasi, terpisahkan dari konteks kulturalnya.

Salah satu efek lain dari banjir informasi satu arah akibat penggunaan gadget yang berlebihan adalah gambaran tentang Dunia Ketiga yang terdistorsi. Dunia ketiga adalah dunia yang bizar, penuh kekerasan, kelaparan, dan kebodohan. Dunia barat adalah dunia yang gemerlap, beradap, mewah, dan terpelajar. Tidak jarang kita membenci bangsabangsa di Dunia Ketiga hanya karena Barat membencinya.

Efek lain, salah satu bentuk ketegangan dan kemelut yang terjadi akibat penetrasi media adalah hancurnya nilai-nilai tradisional dan masuknya nilainilai modern yang destruktif. Pesan media telah menjadi konsumsi intelektual (dan emosional) kita sehari-hari.

Kennichi Ohmae dalam artikel Perilaku Masyarakat Informasi menegaskan bahwa, masyarakat informasi adalah masyarakat yang sangat tergantung pada teknologi informasi. Prioritas diletakkan pada informasi yang terurai, lebih terperinci untuk memenuhi kebutuhan individual, dan bukan informasi yang direproduksi misal secara konvensional.

Penggunaan teknologi informasi mutakhir, khususnya komputer dan bermacam-macam jenis gadget, telah mendorong beberapa masyarakat menstruktur kembali sistemnya. Struktur yang baru itu disebut masyarakat informasi. Daniel Bell dalam The Coming of Post-Industrial Society bercerita tentang tiga sistem sosial: pra-industrialisme, industrialism, dan pasca-industrialisme. Sistem sosial yang terakhir adalah sistem sosial yang berbasis teknologi intelektual dan pemberian jasa. Dalam konseptualisasi Bell, masyarakat pascaindustri mengandung lima dimensi: (1) pergeseran dari ekonomi yang memproduksi barang kepada ekonomi jasa; (2) pertambahan jumlah dan pengaruh kelas professional dan pekerja teknis; (3) pengaturan (organisasi) masyarakat berdasarkan pengetahuan teoritis, yakni pertumbuhan teknologis, dengan metode peramalan dan pengendalian teknologi dan (5) titik berat pada perkembangan metode-metode teknologi intelektual.

Jadi, kunci masyarakat informasi adalah pengelolaan teknologi intelektual, yaitu teknologi yang digunakan untuk mengumpulkan, menyimpan, mengolah, dan mengeluarkan kembali informasi.

Lalu, bagaimana Indonesia? Indonesia adalah negeri ajaib di mana seluruh peradaban hadir sekaligus. Sebagian kita telah memasuki masyarakat informasi, sementara yang lain masih tinggal pada 
zaman industrialism, bahkan pra-industrialisme. Yang mengerikan ialah kenyataan bahwa dalam benturan-benturan peradaban itu, kita cenderung menggabungkan segi-segi yang negatifnya saja. .

Masyarakat informasi di zaman sekarang ini, telah banyak mengalami perubahan. Lahirnya perangkat teknologi baru juga akan menciptakan generasi baru pula. Sebut saja keberadaan beberapa situs jejaring sosial seperti Facebook dan Twitter yang telah menghipnotis para penggunanya, terutama dikalangan remaja yang terus bertukar informasi dalam hitungan detik di-setiap tempat dan waktu.

Sejarah umat manusia, tampak bahwa kita sekarang berada di tengah-tengah ledakan teknologi informasi dengan berbagai pilihan gadget, tingkat akselerasinya pun semakin tinggi. Ledakan informasi ini telah mengguncang dunia Barat, karena kedatangannya yang beruntun. Toffler menyebut Barat sedang menyaksikan sekaratnya gelombang peradaban kedua. Ledakan ini mengguncang negara-negara ketiga secara lebih dahsyat lagi. Bagi mereka, teknologi informasi dan piranti yang mengiringinya datang pada saat gelombang peradaban pertama (peradaban agricultural) masih bercokol dan gelombang peradaban kedua (peradaban industri) masih menyerap. Kedatangan runtunan teknologi informasi yang baru telah mengubah sosisfer dan psikosfer umat manusia. "We are rapidly fabricating a total psychological environment for ourselves," kata Frederick William (1982:12).

\section{METODOLOGI}

Informan yang digunakan dalam penelitian ini adalah siswa pemakai gadget yang berusia 10-12 tahun yang bersekolah di SD Muhammadiyah di Kota Yogyakarta, yakni SD Muhammadiyah Sokonandi, SD Muhammadiyah Karangkajen, dan SD Muhammadiyah Pakel. Anak-anak usia 10-12 tahun sudah mulai mengasah kemampuan, pemahaman dan nalar berpikir mereka sehingga akan membentuk nilai dan norma yang dipengaruhi oleh teman-temannya.

Penelitian ini bertujuan untuk memberikan gambaran tentang perilaku dan praktik konsumsi media gadget melalui metode deskriptif diharapkan mampu memaparkan fenomena secara rinci serta menghadirkan analisis yang lebih mendalam yang tidak mampu diungkapkan dengan metode kuantitatif. Peneliti ingin menggambarkan secara alami tentang gejala dan keadaan dengan tidak menggunakan hipotesis. Wawancara dilakukan bebas, sambil lalu, bahkan kadang tidak disadari oleh informan sendiri. Pengumpulan data dengan jenis pendekatan etnografis yang dilakukan dengan beberapa cara, salah satunya dengan etnografi kontemporer adalah memilih dan membangun relasi yang dekat dengan individual sang informan.

Metode yang digunakan dalam penelitian ini adalah etnografi. Pada tataran praktis, Morley (1974) menyarankan penggunaan metode etnografi dengan melandaskan diri pada thick description-nya Geertz. Ini sejajar dengan pemahaman para pembela cultural studies yang melihat bahwa metode pembongkaran teks dan riset etnografis penting dalam melihat dinamika audiens. Saran-saran menarik dari para peneliti etnografi adalah upaya memperhatikan dan mengkaji sampai sedalam-dalamnya dinamika diri audiens (Siregar, 2007:20).

Informan pertama: Nashwa, usia 10 tahun bersekolah di SD Muhammadiyah Karangkajen Yogyakarta. Dalam keseharian, Nashwa jarang membawa gadget dalam bentuk handphone ke sekolah karena jarak rumah ke sekolah sangat dekat. Orang tua Nashwa termasuk permisif dalam membuat aturan penggunaan gadget di rumah. Terdapat beberapa pilihan gadget yang disediakan oleh orang tua Nashwa yakni handphone, tablet, laptop dan blackberry milik orang tua yang oci digunakan juga oleh Nashwa. Di sekolah semua siswa diperbolehkan membawa gadget, dengan catatan selama jam pelajaran gadget dititipkan kepada guru.

Yasmin, 12 tahun adalah informan kedua yang bersekolah di SD Muhammadiyah Sokonandi Yogyakarta. Berbeda dengan aturan di sekolah Nashwa, SD Muhammadiyah Sokonandi hanya memperbolehkan penggunaan gadget khususnya handphone yang tidak berkamera. Dalam inspeksi mendadak atau sidak yang pernah dilakukan oleh guru sekolah, terdapat gambar-gambar dewasa yang beredar di antara gadget siswa. Inilah yang melatarbelakangi aturan sekolah untuk tidak membawa smartphone ke sekolah. Laptop hanya boleh dibawa ketika siswa sedang belajar mata pelajaran Teknologi Informasi.

Terakhir adalah Salsa, usia 12 tahun bersekolah di SD Muhammadiyah Pakel Yogyakarta. Berbeda dengan Nashwa dan Yasmin, Salsa sebenarnya jarang menggunakan gadget. Beruntung, ketidaktertarikan Salsa terhadap gadget dipengaruhi juga oleh aturan sekolah yang sama sekali tidak memperkenankan siswanya membawa gadget. 
Apabila terdapat informasi penting yang akan disampaikan siswa kepada orang tua, maka sekolah menyediakan telepon umum yang disediakan di koperasi. Siswa bisa menggunakan sarana ini, dengan membayar biaya pulsa.

Ada beberapa implikasi yang jelas terhadap studi komunikasi massa dimana setiap aspek produksi dan penggunaan media massa memiliki dimensi kultural. Orang difokuskan sebagai produser teks media makna budaya atau sebagai 'pembaca teks' dari apa yang mereka ambil dari pemaknaan budaya, dengan implikasinya pada kehidupan sosial. Kita bisa fokus pada teks dan artefaknya (film, buku, koran, artikel) dan bentuk simbolik dan kemungkinan makna mereka. Kita bisa belajar mengenai praktek pembuat produk media atau pengguna media. Komposisi dan perilaku audiens media (praktik antara pilihan dan penggunaan media) selalu terpola secara kultural mulai dari sebelum, setelah dan selama pengalaman bermedia (McQuail, 2010: 113).

Audiens adalah produk dari konteks social (mampư membagikan ketertarikan budaya, pemahaman dan kebutuhan akan informasi) dan tanggapan pada pola tertentu terhadap provisi media. Media juga menggunakan refleksi pola yang lebih luas dari penggunaan waktu, ketersediaan, gaya hidup dan rutinitas sehari-hari. Audiens didefinisikan pada cara yang berbeda tergantung pada tempat, orang, tipe medium tertentu, pada isi pesan, dan pada waktu (McQuail, 1997:2).

Analisis audien digunakan untuk melakukan interpretif dalam konteks penelitian ini dan memahami alasan-alasan para pelaku terhadap tindakan sosial yang mereka lakukan, yaitu cara-cara dari para pelaku untuk mengkonstruksikan kehidupan mereka dan makna yang mereka berikan kepada kehidupan tersebut.

\section{HASIL DAN PEMBAHASAN}

Temuan dan Analisis Perilaku Konsumsi Gadget oleh Siswa SD Muhammadiyah

1. Analisis Isi Media Gadget yang Dikonsumsi Siswa

Hampir keseluruhan informan tidak menggunakan atau tidak membawa gadget ke sekolahan karena aturan ketat yang dibuat oleh pihak sekolah masing-masing. Mereka lebih aman untuk tidak membawa gadget ke sekolah untuk menghindari berurusan dengan pihak sekolah karena hukuman. Di sisi lain, informan juga ingin menunjukkan kepada orang tuanya bahwa dia akan bertanggung jawab dalam pemakaian gadget, yakni menaati peraturan yang ada, dan tidak berlebihan dalam penggunaan gadget.

Berikut adalah pernyataan informan tentang aturan membawa dan mengonsumsi gadget di sekolah masing-masing:

"Di sekolah boleh bawa gadget, tapi kalau sedang pelajaran dititipkan ke bapak atau ibu guru" (Nashwa, 10 tahun, SD Muhammadiyah Karangkajen YK)

Bahkan menurut informan, SD Muhammadiyah Sokonandi secara rutin melakukan inspeksi mendadak sebulan sekali apabila terdapat siswa yang membawa gadget di luar ketentuan sekolah. Tindakan yang diberikan sekolah cukup permisif, hanya dengan pernyataan dari guru bahwa besuk disarankan untuk tidak mengulang lagi. Berbeda dengan SD Muhammadiyah Sokonandi yang mengharuskan orang tua siswa yang mengambil gadget tersebut apabila ditemukan dibawa siswa yang melanggar ketentuan. Inilah yang membuat Yasmin tidak pernah membawa gadget ke sekolah. Karena cukup meminjam handphone milik wali kelas, maka segala kebutuhan komunikasi dengan orang tua sudah terpenuhi.

"Kalau di sekolahku bolehnya hanya bawa handphone tanpa kamera. Kalau ketahuan bawa handphone yang berkamera bisa disita. Trus yang ngambil harus orang tuanya" (Yasmin, 12 tahun, SD Muhammadiyah Sokonandi)

Salsa juga tidak pernah membawa gadget ke sekolah. Apabila tiba-tiba ada pengumuman sekolah pulang cepat, maka yang dilakukan Salsa adalah menuju koperasi sekolah untuk menelpon orang tuanya untuk segera dijemput.

"Di sekolahku nggak boleh bawa handphone. Kalau ketahuan bisa dihukum. Kalau ada yang penting mau telepon orang tua, bisa telepon di koperasi sekolah" (Salsa, 12 tahun, SD Muhammadiyah Pakel)

Tetapi, dengan berbagai aturan ketat yang diberlakukan, masing-masing sekolah sudah mempunyai solusi tersendiri apabila salah satu dari siswa mepunyai kebutuhan yang sangat penting untuk menghubungi orang tuanya. SD Muhammadiyah Pakel sudah menyediakan koperasi yang dilengkapi dengan wartel (warung telepon) di dalamnya. Siswa bisa mengunakan sarana tersebut dengan membayar biaya pulsa.

SD Muhammadiyah Sokonandi berbeda dalam memberikan solusi. Apabila terdapat siswa yang 
mempunyai keperluan untuk menghubungi orang tua di rumah adalah dengan meminjam handphone milik wali kelas masing-masing dengan cara menulis SMS. Penggunaan handphone tidak berkamera masih diperkenankan. Gadget lain misalnya laptop hanya diperbolehkan ketika pelajaran Teknologi Informasi.

Aturan paling longgar berlaku di SD Muhammadiyah Karangkajen. Sekolah memperbolehkan siswa membawa handphone jenis apapun dengan dititipkan ke bapak atau ibu guru di kelas. Dahulu, aturan lebih longgar, gadget apa pun boleh dibawa. Tetapi karena pengalaman pernah ada siswa yang kehilangan gadget di sekolah, maka sekarang tidak diperkenankan lagi membawa lebih dari 2 gadget ke sekolah.

Ketiga sekolah masing-masing informan menerapkan 2 kali jam istirahat yakni pagi jam 09:00 dan siang hari jam 11:00. Ditambah jam untuk sholat dan makan siang. Jadi praktis hanya pada saat jamjam tertentu saja siswa menggunakan gadget. Dari tiga informan ini, kegiatan bersosialisasi dengan teman masih merupakan pilihan kegiatan utama pada waktu jam istirahat dibandingkan dengan bermain gadget.

Konsumsi gadget akan lain ceritanya kalau sudah di rumah. Ketika sudah keluar dari bingkai aturan sekolah, maka masing-masing informan mempunyai kebiasaan yang berbeda dalam pemakaian gadget. Salsa paling sederhana dalam mengkonsumsi gadget. Handphone hanya akan digunakan ketika dia mempunyai masalah tugas sekolah dan akan menanyakan hal tersebut kepada teman yang lain, misal menanyakan PR (pekerjaan rumah). Jadi handphone digunakan hanya untuk mengirimkan pesan berupa SMS (short message service). Komputer yang tersedia di rumah hanya sesekali saja dipakai untuk sekedar bermain game dengan adiknya. Peneliti melihat, Salsa adalah informan yang cepat memahami dalam melihat kehadiran teknologi informasi. Dibandingkan dengan dua informan lain, gadget yang dimiliki oleh Salsa terbilang paling sederhana. Tidak ada fitur lengkap seperti yang dimiliki oleh Yasmin dan Nashwa. Salsa juga tidak punya satu pun jejaring sosial yang dia ikuti. Berbeda dengan Nashwa dan Yasmin yang juga aktif ber-twitter, facebook dan istagram untuk aplikasi foto.

Yasmin adalah informan yang paling sering menggunakan gadget untuk keperluan membuka laman jejaring sosial yang dia miliki. Rata-rata 2-3 jam dalam sehari Yasmin menggunakan gadget untuk bersosialisasi dengan teman-temannya melalui jejaring sosial.

"Aku seringnya pake BB mama untuk buka twitter, kalau BB papa lebih lengkap bisa buat youtube sama faceboak lebih cepet aksesnya. Trus kalau pake laptop untuk main instagram sama game online" (Yasmin, 12 tahun).

Fasilitas di rumah Yasmin juga dilengkapi dengan wifi, sehingga konsumsi gadget tidak menjadi masalah. Uang pulsa Rp20.000,00 (dua puluh ribu rupiah) setiap bulan yang diberikan orang tuanya semata-mata hanya digunakan untuk membeli pulsa handphone.

Hampir sama dengan Yasmin, informan Nashwa juga diberi jatah uang Rp10.000,00 (sepuluh ribu rupiah) setiap bulan untuk mengisi pulsa handphone. Di rumah sudah ada fasilitas wifi yang bisa digunakan seluruh keluarga. Bahkan, orang tua Nashwa justru memberikan beberapa fasilitas yang bisa digunakan dalam fitur gadget.

"Sebentar lagi mama sama papa mau umroh, jadi aku dikasih tau sama papa cara menggunakan skype, biar besuk kalau ditinggal umroh aku tetap bisa berkomunikasi dengan mereka." (Nashwa, 10 tahun).

Ini adalah hal menarik, rupanya orang tua generasi millennial tidak kemudian membatasi anak dalam penggunaan gadget tetapi justru memberikan fasilitas tambahan yang bisa memberikan manfaat lebih bagi anak dan komunikasi keluarga.

Temuan lain adalah pola asuh keluarga. Salsa adalah informan yang orang tuanya (ibu) berlatar belakang tingkat sekolah dasar (pondok pesantren tradisional). Terdapat pembatasan dalam hal penggunaan gadget di dalam rumah. Implikasinya adalah, Salsa tidak begitu heroik seperti temantemannya dalam mengonsumsi gadget dan perkembangan media sosial.

"Aku nggak suka facebook, jadi nggak buat. Menurutku buka facebook hanya buang waktu saja dan nggak penting. Aku nggak boleh buat facebook soalnya kata papa bisa diculik" (Salsa, 12 tahun)

Inilah yang dikhawatirkan oleh orang tua Salsa dan juga pernah dikatakan oleh Peter L. Berger, bahwa saat rasionalitas teknologi modern memasuki masyarakat tradisional, kesatuan lama menjadi pecah. Hubungan-hubungan kosmis antara semua makhluk dan semua barang terputus. Rasionalitas ditata menjadi komponen-komponen yang dapat dipahami dan dimanipulasi secara terpisah-pisah. Sejauh komponensialitas meluas sampai bidang hubungan sosial dan sampai pengalaman indiviciu akan dirinya sendiri, komponensialitas itu dialami sebagai mencerabut dan mengasingkan. 


\section{Macam Gadget yang dipakai}

Nashwa dibelikan handphone oleh orang tuanya sejak kelas 2 SD ketika berumur 8 tahun, dan baru tahun lalu orang tua memberikan tablet yang bisa digunakan sewaktu-waktu. Berbeda dengan Yasmin, Nashwa memperoleh kebebasan menggunakan handphone mulai kelas 4 atau 2 tahun yang lalu, hampir bersamaan dengan Salsa yang juga mendapatkan handphone di kelas 4 SD.

Nashwa paling banyak menggunakan gadget di antara informan yang lain. Orang tua memberikan handphone dan tablet untuk Nashwa, tetapi apabila menghendaki akan memakai gadget lain milik orang tuanya misal laptop atau gadget lain yang lebih canggih, maka orang tua di rumah akan meminjamkannya.

"Tablet ini sekarang punya saya, soalnya ayah sudah beli yang lebih bagus lagi ...Tapi tablet ini hanya dipakai kalau hari Sabtu dan Minggu saja" (Nashwa, 10 tahun)

Sebenarnya, Yasmin hanya diberikan smartphone oleh orang tuanya. Tetapi ketika di rumah ia akan berselancar menggunakan blackberry milik orang tuanya. Selain itu, Yasmin juga sering menggunakan laptop milik orang tuanya.

Terdapat kecenderungan informan untuk menggunakan gadget yang lebih simpel dan memberikan fitur lengkap. Komputer PC yang tersedia di rumah masing-masing informan sudah mulai ditinggalkan. Hanya akan digunakan ketika gadget lain sedang bermasalah, misal rusak.

"Aku nggak suka pake komputer soalnya fasilitasnya nggak lengkap. Kalau laptop bisa dipakai macam-macam. Layarnya besar, jadi lebih seru ..."(Yasmin, 12 tahun).

Salsa adalah informan yang paling sedikit mengonsumsi gadget. Hanya ada satu handphone sederhana yang dimiliki dan digunakan. Sesekali menggunakan fasilitas PC Komputer yang ada di rumah.

\section{Alasan menggunakan gadget}

Ketiga informan memberikan alasan yang sama di dalam menjawab pertanyaan mengapa menggunakan gadget, yakni untuk berkomunikasi dengan orang tua. Fasilitas atau fitur lain di dalam gadget adalah bonus bagi mereka, karena dengan gadget ternyata mereka bisa berkomunikasi dengan teman-temannya dengan lebih dekat dan seru yakni dengan aktif dalam jejaring sosial.

Bahkan dalam penggunaan lebih lanjut, ketiga siswa ini justru terbantu dengan hadirnya gadget dalam kehidupan mereka, yakni menolong mereka dalam mengerjakan tugas sehari-hari berkaitan dengan mata pelajaran di sekolah.

Walaupun keberadaan gadget bagi mereka adalah penting dalam keseharian, tetapi mereka masih mempunyai waktu untuk bersosialisasi secara fisik dengan lingkungan sekitar. Mereka tidak kemudian menjadikan piranti teknologi sebagai 'Tuhan baru'. Tidak seperti yang dikhawatirkan bahwa dengan wujud media dan bahasa yang telah terdistorsi, media menghadirkan realitas imajiner, menggiring khalayak memasuki gerbang negeri hedonisme dan konsumerisme. Jika salah tangan, media memang menjadi hegemoni yang secara efektif mengkooptasi dan menjerumuskan rakyat tanpa perlu kekerasan.

Gadget mempunyai peranan penting bagi siswa dalam memberikan identitas, menyediakan kawan, menambah penafsiran tentang kejadian-kejadian, dan secara tidak langsung mengarahkan audien pada pengambilan keputusan. Gadget memuaskan kebutuhan penggunanya, menentukan cara berpikir dan cara manusia mengolah informasi tentang lingkungan.

\section{KESIMPULAN}

Hasil penelitian ini menunjukkan bahwa sebenarnya tidak perlu ada yang dicemaskan dalam melihat perilaku konsumsi anak terhadap gadget di sekolah Muhammadiyah di Kota Yogyakarta. Dalam penggunaannya, anak sudah cerdas dalam memilih informasi yang disajikan dalam semua gadget yang digunakan. Mereka menggunakan gadget untuk keperluan komunikasi yang berhubungan dengan kegiatan di sekolahnya, atau berkomunikasi kepada orang tua. Bahkan dalam penggunaan yang lebih luas, justru gadget bisa menambah wawasan mereka dalam mendapatkan informasi baru terkait mata pelajaran di sekolahnya.

Tidak ada penggunaan yang berlebihan dalam konsumsi gadget bagi siswa SD. Rata-rata informan menggunakan gadget 2-3 jam sehari di rumah, sementara waktu sekolah mereka 8 jam sehari.

Hanya ketika waktu luang saja mereka menggunakan gadget untuk keperluan rekreasi, selebihnya adalah untuk berkomunikasi dengan sesama teman sekolah atau saudara.

Content media yang biasa dikonsumsi pun masih dalam porsi wajar untuk anak-anak, yakni SMS pada handphone, sesekali game online ketika menggunakan tablet, dan jejaring sosial facebook dan twitter yang beranggotakan teman-teman 